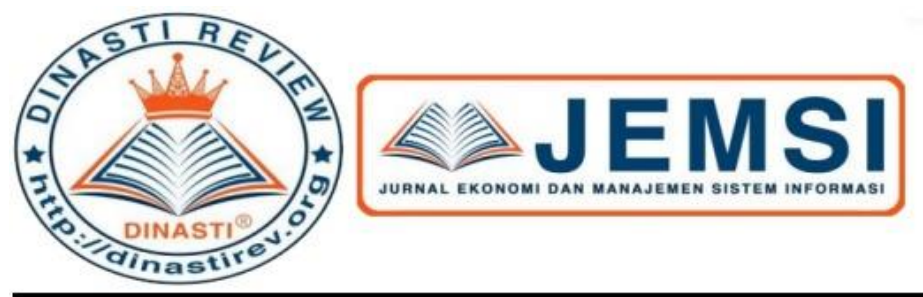

+62 878-9658-6407

087896586407 ()

https://dinastirev.org/JEMSI (-)

editor@dinastirev.org (G.

\title{
BUSSINES ETHICS PADA PT. BINTANG TIMUR SAKTI
}

\section{Dewi Wahyuni}

Universitas Mercu Buana, Jakarta,Indonesia

ARTICLE INFORMATION

Received: 37 April 2020

Revised: 17 Juni 2020

Issued: 7 Juli 2020

Corresponding author: first author E-mail:

dewiwahyuni630@gmail.com

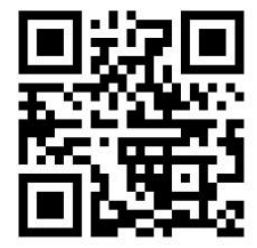

DOI:10.31933/JEMSI
Abstrak: Etika Bisnis dalam perusahaan sangat berperan penting, karena suatu perusahaan bisa dikatakan berhasil bukan karena berlandaskan moral saja dan manajemen yang baik, dan harus memiliki etika yang baik. Adapun tujuan penulisan pembuatan paper ini adalah meneliti bahwa penerapan business ethics di PT. Bintang Timur Sakti dapat membawa perusahaan dalam mencapai visi dan misi perusahaan. Serta untuk memastikan etika bisnis yang dijalankan atau diterapkan oleh perusahaan sudah sesuai dengan norma-norma dan adat yang berlaku atau belum. Metode penelitian yang digunakan oleh penulis yaitu metode penelitian deskriptif kualitatif dan metode studi literature. Hasil yang ditemui penulis adalah penerapan bisnis etik yang baik dan sesuai memberikan pengaruh secara signifikan terhadap citra dan etos kerja PT. Bintang Timur Sakti.

Kata Kunci: Etika, bisnis, business ethics

\section{PENDAHULUAN}

Di era sekarang ini, Semakin canggihnya teknologi dimasa sekarang ini akan sangat membandu dalam perkembangan sebuah bisnis. Karena Teknologi yang canggih sangat dibutuhkan dalam proses bisnis gunanya untuk meringankan pekerjaan itu sendiri, dan dalam menjalannkannya maka diperlukan etika yang sebagaimana mestinya. Segala sesuatu yang dilakukan manusia akan berhasil baik jika dilakukan dengan cara yang benar dan sesuai dengan aturan-aturan moral yang berlaku. Dalam suatu bisnis juga terdapat kode etik yang harus diterapkan, seperti kode etik SDM, Keuangan, Pemasaran, guna untuk meniti kesuksesan dalam bisnis yang dijalankan.

Dalam perusahaan Etika bisnis memiliki fungsi, dalam menjalankan bisnis perlu melandaskan moral manajaemen dan etika bisnis yanh baik pastinya. Oleh sebab itu perlu di dalam perusahaan harus bias meningkatkan mutu dan bias memenuhi permintaan yang sesuai dan yang dibutuhkan oleh masyarakat. Dalam kegiatan bisnis banyak hal-hal yang melanggar etika bisnis, Banyak perilaku yang bias merugikan perusahaan kaena perbuatan yang melanggar etika. 
Dalam pelaksanaan keseharian perusahaan, perusahaan tunduk pada berbagai etika, salah satunya adalah etika bisnis. Dalam menerapkan Etika Bisnis dalam perusahaan banyak yang perlu di pertimbangakan dari mulai kepuasan konsemen dan perlindungan konsumen. Etika adalah suatau perilaku yang bias dikatakan bedar atau salah, dan etika yang baik atau buruk dlam menjalankan kesehariannya terhadap lingkungan internal ataupun eksternal. Dalam sikap perorangan di dalam konteks social bias menentukan apakah perilaku tersebut bias dikatakan etis atau tidak etis. Dengan memegang prinsip etika dam moral bisnis yang baik, kita bisa bersaing secara sehat dengan perusahaan lain tanpa ada pihak yang tersakiti.

Banyak faktor yang bisa mempengaruhi dalam kegiatan berbisnis. Dalam kegiatan berbisnis di dalam masyarakat perlu cara agar terjalinnya suatu hubungan yang harmonis dalam menjalankan kegiatan sosial bermasyarakat guna mendapatkan keuntungan dari berbagai pihak dari proses bisnis. Tetapi dalam berbisnis untuk dapat mencapai harapan yang sesuai dengan tujuan perlu adanya pembatasan kepentingan atau hak-hak orang lain.

Perilaku dalam kegiatan berbisnis merupakan sesuatu yang sangat penting dalam menjalankan suatu bisnis. Apabila ada bisnis yang tidak etis bisa sangat merugikan bisnis itu sendiri bisa dilihat dari perspektif jangka panjang. Bisnis yang baik bukna bisnis yang menguntungkan, akan tetapi bisnis yang baik bisa menguntungkan secara moral.

Dalam perilaku yang baik dan sesuai dengan norma-norma bisnis yang berlaku. Bisnis bisa berkaitan dengan hokum jika ada permasalahan yang timbul dalam berbisnis, Dan Tanpa kita sadari tenyata banyak kasus pelanggaran etika bisnis yang secara tidak sadar tenyata, kita ikut menyaksikan kegiatan itu, mulai dari pelanggaran etika bisnis yang sering dilakukan oleh para pebisnis dan tidak bertanggung jawab di Indonesia.

Penulis meyakini bahwa penerapan etiak bisnis yang baik dalam suatu perusahaan, untuk membentuk perusahaan lebih baik dan memiliki daya saing yang tinggi. Perlunya Perencanaan yang strategis dan terorganisasi secara transparan.

Adapun tujuan penulisan pembuatan paper yaitu untuk memenuhi syarat slah satu tugas yang dosen berikan di mata kuliah Business Ethics \& Good Governance, dan serta untuk memberikan bukti bahwa penerapan business ethics di PT. Bintang Timur Sakti dapat membawa perusahaan dalam mencapai visi dan misi perusahaan. Serta untuk memastikan etika bisnis yang dijalankan atau diterapkan oleh perusahaan sudah sesuai dengan norma-norma dan adat yang berlaku atau belum.

\section{KAJIAN PUSTAKA \\ Pengertian Etika}

Menurut Prakoso (2015), Etika profesi adalah etika khusus yang mempunyai tugas dan tanggung jawab kepada ilmu dnan profesi yang disandangnya.

Sementara itu, Menurut Bertens (1993:4) bahwa etika adlah ilmi yang mempelarkan tentang adat dan kebiasaan, termasuk dalam moral yang mengandung nilai dan norma yang berlaku sebagai pegangan hidup seseorang atau sekelompok untuk mengatur tingkahlakunya.

Menurut Webster Dictionary, etika yaitu suatu ilmu disiplin mengenai tugas dan kewajiban, baik atau buruknya nilai moral. Etika adalah cabang filosofi yang berkaitan dengan pemikiran benar atau salah. Simorangkir menilai etika adalah hasil usaha yang sistematik yang menggunakan rasio untuk menafsirkan mengenai moral indoividu dan untuk 
menetapkan aturan dalam mengendalikan perilaku dan nilai - nilai yang terkandung, untuk bisa dijadikan pedomanan hidup. Menurut Satyanugraha yaitu, etika sebagai nilai-nilai dan norma moral dalam suatu masyarakat.Sebagai ilmu, etika juga bisa diartikan pemikiran moral yang mempelajari tentang apa yang harus dilakukan atau yang tidak boleh dilakukan.

\section{Fungsi Etika}

Menurut Frenz Magnis-Suseno dalam I Gede A. B Wiranata (2005:47) dalam bukunya yang menuliskan etika fungsinya untuk membantu manisua mencari orientasi secara kritis dalam kehidupan yang membingungkan. Etika yaitu suatu pemikiran yang sistematis tentang kehidupan msyarakat dalam menuju modern social berpotensi bermoral

Etika bisa juga dikatakan suatu ilmu, yang merupakan suatu filsafat yang bersifat praktis, normative dan fungsional, etika juga bisa digunakan dalam kehidupan sehari-hari. Etika bisa juga dikatakan norma-norma dalam kehidupan karena bisa memberikan bukti perbuatan seseorang manusia.

\section{Jenis-Jenis Etika}

Menurut K. Bertens (2004:15-22) etika dapat dibagi dua bagian :

a. Etika Diskriptif juga melukiskan tingkah laku moral dalam arti luas, misalnya adat kebiasaan, anggapan-anggapan tentang baik dan buruk, serta tindakan-tindakan yang diperoleh atau tidak diperoleh. Etika mempelajari mengenai moralitas yang ada di individu-individu tententu.

b. Etika Normatif merupakan merupakan diskusi-diskusi yang paling menarik tentang masalah moral. Para ahli melibatkan diri sendiri untuk memberikan penilaian tentang perilaku manusia. Dan penilaian ini dibentuk atas dasar norma-norma yang berlaku.

Etika Deskriptif hanya menggambarkan norma-norma dan tidak mencari tahu kembali apakan norma-norma tersebut benar atau tidaknya. Etika Normatif bertujuan merumuskan prinsip-prinsip etis yang dapat dipertanggung jawabkan. Etika Normatif tidak membahas gejala-gejala, melainkan tentang apa yang sebenarnya harus merupakan tindakan kita. Dalam etika normative, normanorma dinilai dan sikap manusia ditentukan.

\section{Definisi Bisnis}

Pengertian bisnis menurut para Ahli:

1. Bisnis adalah usaha yang dijalankan guna untuk mendapatkan keuntungan. Menurut (Kasmir dan Jakfar,2012:7).

2. Dalam buku milik Raymond E Glos yang isinya bisnis adalah kegiatan yang membahas kegiatan yang diorganisasikan oleh orang bekerja di bidang perniagaan dan isndustri (Umar, 2005:3)

\section{Fungsi Bisnis}

Menurut Madura (2007,p12) Fungsi bisnis dapat disimpulkan :

1. Bagaimana cara sumber daya manusia beralih dengan mesin yang perusahaan sudah sediakan.

2. Bagaimana bagian marketing memasarkan produk dan jasa untuk segera di promosikan ke semua pelanggan. 
3. Bagaimana system keuangan yang perusahaan gunakan untuk dana operasional bisnisnya.

\section{Fungsi Bisnis}

Indriyo Gito Sudarmo (1993 : 3), ada berbagai macam jenis bisnis, sebagai berikut :

1. Ekstratif merupakan kegiatan dalam bidang pertambanganatau bahan-bahan yang terkandung dalam perut bumi.

2. Agraria adalah bisnis dalam bidang pertanian.

3. Industri yaitu bisnis yang bergerak dibidang industry.

4. Jasa, yaitu bisnis yang bergerak dibidang jasa untuk menghasilkan produk yang tidak berwujud.

\section{Definisi Bisnis Etik}

Asal mula etika berasal dari bahasan Yunani artinya yaitu ethos dan dalam bentuk jamak adlah ta etha. Etika dan moral memiliki arti yang sama, namun dalam kegiatan seharihari ada perbedaan dlam perbuatannyang dikaji atau dinilai, dan etika dipakai untuk mengkaji system nilai yang ada di dalam kelompok masyarakat tertentu. Etika bisnis adalah suatu ilu yang mempelajari perilaku manusia mua itu baik atau buruk dalam menjalankan pekerjaan di perusahaan, ada 3 etika bisnis yang dijalankan yaitu makro, system ekonomi yang keseluruhan.

\section{Fungsi Bisnis Etik}

Menurut K. Bertens (2013), 3 tujuan yang bisa dicapai dalam penerapan etika bisnis :

1. Menanamkan atau meningkakan kesadaran akan adanya demensi etis dalam bisnis. Menanamkan, jika sebelumnya kesadaran itu tidak ada, meningkatkan bila kesadaran itu sudah ada, tapi masih lemah dan ragu. Orang yang mendalami etika bisnis diharapkan memperoleh keyakinan bahwa etika merupakan segi nyata dari kegiatan ekonomis yang perlu diberikan perhatian serius.

2. Memperkenalkan argumentasi moral khususnya dibidang ekonomi dan bisnis, pebisnis/calon pebisnis dalam menyusun argumentasi moral yang tepat.

3. Membantu calon pebisnis, untuk menentukan sikap moral yang tepat didalam profesinya

(kelak).

\section{Pentingnya Etika Bisnis}

Bisnis dapat dikatakan suatu proses keseluruhan dari produksi yang memaksimalkan keuntungan perusahaan dan dapat meminimalkan biaya produksi. Dan oleh karena itu, bisnis seringkali menetapkan pilihan strategis berdasarkan nilai dimana pilihan tersebut didasarkan atas keuntungan dan kelangsungan hidup perusahaan. Muhammad (2004: 60-61) mengatakan, pentingnya dalam etika bisnis dalam kelangsungan perusahaan adalah sebagai berikut:

1. Etika Bisnis dapat dipusatkan untuk menyelaraskan kepentingan strategis suatu bisnis.

2. Etika bisnis melakukan perubahan kesadaran masyarakat mengenai bisnis bahwa bisnis tidak dapat dipisahkan dari etika. 


\section{Prinsip Etika Bisnis}

Banyak prinsip-prinsip yang mempunyai tujuan memberikan acuan yang harus ditempuh perusahaan untuk bisa menjadi lebih baik lagi, menurut Muslich (2004: 18-20) yaitu :

1. Prinsip Ekonomi Perusahaan memiliki wewenang yang sesuai dengan bidang yang akan dilakukan sesuai dengan visi misi yang dimiliki perusahaan, selanjutnya kan dikembangkan visi misi tersebut untuk mensejahterakan para komunitas.

2. Prinsip Kejujuran yang menjadi nilai utama dalam mendukung berhasilnya perusahaan. Dan ada hubungannya mengenai lingkungan bisnis, kejujuran seluruh karyawan sangat dikaitkan oleh aktivitas bisnis. Karena dengan kejujuran yang dimiliki karyawan di dalam perusahaan akan menaruhkan kepercayaan yang tinggi bari perusahaan tersebut.

3. Ada prinsip niat baik dan tidak baik yang sangat terkait dengan kejujuran yang dimiliki karyawan, karena prilaku jahat bisa menghancurkan visi misi dan tujuan yang sebelumnya sudah dibuat dalam perusahaan.

4. Prinsip adil adalah yang perusahaan terapkan untuk bersikap adil kepada system bisnis yang terkait dengan pihak-pihak bisnis.

5. Cermin prinsip hormat pada diri sendiri adlah salah satu penghargaan yang mengandung nilai positif pada diri sendiri. Hal ini bisa dengan menjaga nama baik merupakan pengakuan atas keberasaan perusahaan tersebut.

\section{METODE PENELITIAN}

Metode penelitian yang digunakan oleh penulis adalah penelitian deskriptif kualitatif yang digunakan untuk meneliti pada kondisiobyek yang alamiah dan sebagai lawannya bisa bereksperimen dimana di dalam penelitian bisa di jadikan kunci, dan sumber data yang dilakukan yaitu secara purposive dan snowball, teknik yang digunakan dalam pengumpulan datayang bersifat induktif atau kualitatif, (sugiyono:2011), dan metode studi literatur Penelitian kepustakaan dan studi pustaka/riset pustaka meski bisa dikatakan mirip akan tetapi berbeda. Studi pustaka adalah istilah lain dari kajian pustaka, tinjauan pustaka, kajian teoritis, landasan teori, telaah putsaka (literature review), dan tinjauan teoritis. Yang dimaksud penelitian kepustakaan adalah penelitian yang dilakukan hanya berdasarkan atas karya tertulis, termasuk hasil penelitian baik yang telah maupun yang belum dipublikasikan (Embun, 2012).

\section{HASIL DAN PEMBAHASAN \\ Profil Perusahaan}

PT. Bintang Timur Sakti, adalah seorang Kontraktor Teknik dengan keahlian dalam desain \& membangun proyek. Sejak didirikan pada tahun 1990, kami telah dipercaya dengan banyak proyek industri. Saya benar-benar percaya kepercayaan ini diberikan karena kami selalu berusaha untuk memberikannya layanan tepat waktu, tanpa mengurangi kualitas dan keamanan. 
PT. Bintang Timur Sakti (BTS), adalah Engineering Contractor bisa perushaan yang berdiri dan bergerak di bidang Rancang Bangun untuk pekerjaan dalam instalasi Mekanikal dan Elektrikal. Berbagai proyek komersial dan industrial telah dipercayakan oleh klien untuk dikerjakan oleh BTS. Kepercayaan ini didapat karena kami akan selalu berupaya memberikan pelayanan berkualitas dengan biaya yang ekonomis.

Dengan didukung oleh manajemen yang terpadu dan sumber daya manusia yang mempunyai semangat tinggi, BTS dapat menyelesaikan proyek-proyek sesuai dengan jadwal dan anggaran yang ditetapkan tanpa mengabaikan kualitas, kecepatan, keamanan, dan kepentingan klien.

\section{Visi Misi Perusahaan}

1. Visi

kami bercita-cita untuk meningkatkan kenyamanan klien, dengan menyediakan instalasi dengan persyaratan perawatan yang tidak rumit

2. Misi

untuk memberikan layanan terbaik bagi klien, baik dari segi biaya, desain \& keandalan bangunan, serta ketepatan waktu"

\section{Etika Bisnis PT. Bintang Timur Sakti}

1. Etika Perusahaan Terhadap Internal

a. Tanggung jawab karyawan

1. Semua karyawan bisa bertanggung jawab atas pelaksanaan standar norma dalam etika termasuk menjalankan pengawasan dalam kegiatan akuntansi.

2. Kebijakan untuk menjadi whistle blower; Jika ada sesuatu yang mencurigai makan secara tidak langsung akan terjadi pelanggaran terhadap undang-undang peratuak kode etik, Pedoman Tingkah Laku atau kebijakan Perseroan tanpa adanya persetujuan yang benar, atau jika percaya bahwa kita diminta untuk melakukan suatu tindakan yang tidak wajar atau melawan hukum, atau jika mempunyai pertanyaan tentang cara terbaik untuk mengambil tindakan dalam situasi khusus, maka harus dengan cepat menghubungi salah satu dari yang berikut ini :
a. Atasan anda
b. Pimpinan Unit SDM
c. Pejabat Unit Kerja Kepatuhan
d. Pejabat Unit Kerja Legal
e. Pimpinan Satuan Kerja Audit Intern
f. Direktur Utama, atau
g. Direktur lainnya.

3. Mempelajari secara detil mengenai pedoman etika usaha dan perilaku yang baik dalam bekerja. Karena setiap insan harus memahami standar etika yang dituangkan dalam Pedoman Etika Usaha dan Tata Perilaku

4. Menghubungi atasan langsung, Unit Kerja Human Capital \& General Affairs, apabila Insan mempunyai pertanyaan mengenai pelaksanaan Pedoman Etika Usaha dan Tata Perilaku 
5. Segera membicarakan kepada pihak yang sidah di tetapkan oleh direksi, apabila ada masalah yang mengenai pelanggaran kepada Pedoman Etika Usaha dan Tata perilaku.

6. Memahami prosedur yang dipakai untuk memberitahukan atau melaporkan kemungkinan pelanggaran terhadap Pedoman Etika Usaha dan Tata Perilaku

7. Bersedia untuk bekerjasama dalam proses investigasi terhadap kemungkinan pelanggaran terhadap Pedoman Etika Usaha dan Tata Perilaku

b. Tanggung jawab manajemen

Membangun dan menjaga budaya kepatuhan terhadap Pedoman Etika Usaha dan Tata Perilaku melalui:

1. Mendukung kepatuhan terhadap Pedoman Etika Usaha dan Tata Perilaku

2. Menjalankan pengawasan dengan teratur mengenai program-program yang akan mendorong lepatuhan pedoman etika usaha dan perilaku.

3. Selalu memberikan contoh yang baik dengan bersikap bain dalam sehari-hari.

4. Selalu Memastikan bahwa setiap insan taan pada pedoman etika usaha untuk terciptanya suatu pencapaian untuk kerja.

\section{ETIKA PERUSAHAAN TERHADAP EKSTERNAL}

\section{Etika Perusahaan dengan Pelanggan}

Hal yang utama dalam menjalin hubungan yang baik antara kepuasan dan kepercayaan pelanggan dengan cara :

1. Menjual produk yang sesuai dengan standar yang sudah di tetapkan.

2. Selalu menindaklanjuti semua keluhan pelanggan dan tidak adanya diskriminasi terhadap pelanggan.

3. Selalu melakukan promosi yang sehat, fair, jujur dan tidak menyesatkan dan bisa diterima dikalangan masyarakat.

\section{Etika Perusahaan dengan Pesaing}

Menempatkan pesaing sebagai pemacu peningkatan diri dan introspeksi dengan cara:

1. Melakukan market research dan market intelligent untuk mengetahui posisi pesaing.

2. Selalu bersaing dengan cara yang sehat dan selalu mengutamakan keunggulan produk dan layanan.

\section{Etika Perusahaan dengan Mitra Kerja}

Untuk menjalin hubungan yang harmonis dengan mitra kerja, makan perlu adanya rasa kepercayaan dan saling menghargai, karna dalam bisnis apabila tidak ada rasa kepercayaan dengan mitra kerja kita bisnis yang sedang dijalankan akan merasa sulit berkembang karena, bisa saja lawan mitra kerja kita masih belum yakin berbisnis dengan kita karna kurang adanya rasan kepercayaan, bagaimana cara mengatasi masalah tersebut, tentunya harus ada kaidah-kaidah bisnis dengan mitra kerja agar berjalan sesuai yang di inginkan:

1. Membuat perjanjian yang saling menguntungkan dalam kegiatan bisnis, sesuai dengan atauran prosedur.

2. Sangat berharap mendapatkan hasil yang baik dan optimal sesuai dengan standar yang berlaku.

3. Membangaun komunikasi yang baik dengan mitra kerja agar bisa mendapatkan solusi yang terbaik dalam peningkatan kinerja. 


\section{Etika Perusahaan mengenai keterbukaan dan kerahasiaan informasi}

Perusahaan mempunyai kewajiban untuk menjaga kerahasiaan informasi yang di peroleh dalam setiap kegiatan bisnis, oleh karena itu setiap insan wajib

1. Melindungi informasi rahasia, tidak membocorkan informasi rahasia perusahaan kecuali diijinkan dan diatur dalam code of conduct.

2. Setiap dewn komisaris perusahaan dilarang menyalahgunakan informasi perusahaan untuk kepentingan pribadi atau kelompok.

\section{PEMBERLAKUAN PELAKSANAAN KODE ETIK}

Sesuai dengan Kode Etik dan Pedoman Tingkah Laku, Perseroan menjalankan kode etik yang berlaku bagi seluruh level organisasi, yaitu Mulai dari manajemen hingga seluruh karyawan Perseroan. Segenap jajaran Perseroan setuju berkomitmen bahwa :

1. Bertindak dengan integritas serta menahan diri agar tidak menyalahgunakan pengetahuan dan kesempatan yang didapat dari kedudukannya di Perseroan.

2. Tiap keputusan atau perbuatan dan hasilnya harus pantas/layak bagi semua pihak dalam transaksi serta wajar dipandang dari segi integritas dan profesionalisme.

3. Dalam bertindak dan membuat keputusan, baik dalam hubungan maupun atas nama Perseroan, harus jujur dan dapat dipercaya.

\section{PENEGAKAN PELAKSANAAN KODE ETIK}

1. Segera melaporkan setiap pelanggaran yang mungkin terjadi terhadap Kode Etik atau Pedoman Tingkah Perseroan kepada Pimpinan SDM atau pihak-pihak lain yang ditunjuk.

2. Apabila terjadinya pelangaran Kode Etik terhadap Pedoman Tingkah Laku yang dapat berakibat tindakan disipliner, termasuk penghentian kerja atau pemutusan hubungan kerja.pedoman tingkah laku bisa saja dikaitkan dengan hokum pidana atau hokum perdata bagi karyawan atau perseroan sendiri.

3. Akan melaporkan atau menindak lanjuti apabila terjadi pelanggaran atas pedoman etika usaha dan tata perilaku.

4. Segera memperbaiki segala kekurangan dan penilaian atas pelaksanaan tata perilaku dan pedoman etikas usaha.

5. Akan memberikan tindakan indisipliner yang sesuai.

\section{KESIMPULAN DAN SARAN}

Ada beberapa faktor yang dapat mempengaruhi dlam kegiatan berbisnis. Seperti kegiatan social, kegiatan bisnis da nada banyak cara agar terjalin dengan baik di masyarakat. Dalam berbisnis tentunya keuntungan yang dicari itu suatu hal yang sangat wajar, untuk tercapainya suatu tujuan dlam kegiatan berbisnis dan tentunya ada hal yang membatasi. Yaitu kepentingan hak-hak orang lain.

Untuk menjadi perusahaan berkelas dunia, banyak prestasi yang sudah diraih PT Bintang Timur Sakti selama ini dapat dibanggakan. Salah satu strategis untuk mencapat visi dan misinya, yaitu kami bercita-cita untuk meningkatkan kenyamanan klien, dengan menyediakan instalasi dengan persyaratan perawatan yang tidak rumit, dan untuk 
memberikan layanan terbaik bagi klien, baik dari segi biaya, desain \& keandalan bangunan, serta ketepatan waktu. Penarapan Etika Bisnis memberikan manfaat untuk meningkatkan reputasi dalam berhubungan bisnis, karena pengelolaan perusahaan yang baik akan menarik minat dan kepercayaan investor. Disamping itu dengan adanya nilai-nilai yang menjadi standar etika bisnis dapat meminimalkan agency cost dan menurunkan cost capital.

\section{DAFTAR RUJUKAN}

Abintaro Prakoso, Etika Profesi Hukum, Laksbang Justitia, (Surabaya, 2015).

Bertens, K, Etika, Jakarta: PT Gramedia Pustaka Utama, 1993

A.B Wiranata, I Gede, 2005, Dasar-dasar Etika dan Moralitas : Pengantar Kajian Etika Profesi Hukum, Citra Aditya Bakti, Bandung.

Bertens, K. (2004). Etika. Jakarta: PT Gramedia Pustaka Utama.

Kasmir, Jakfar. (2012). Studi Kelayakan Bisnis. Edisi Revisi. Jakarta : Kencana

Umar, Husein. (2005). Studi Kelayakan Bisnis, Edisi 3. Jakarta: Gramedia Pustaka Utama

Madura, Jeff. 2007. Introduction To Business. Edisi Keempat. Jakarta : Salemba Empat.

Indriyo Gitosudarmo, Manajemen Keuangan, BPFE, Yogyakarta. 1993

Hapzi, A.2020. Modul Businees Ethics \& Good Governance. Universitas Mercu Buana. Jakarta

Bertens, K. 2013. Etika. Yogyakarta: Kanisius

Alimin, Muhammad. Etika dan Perlindungan Konsumen dalam Ekonomi Islam, Yogyakarta: BPFE, 2004.

Muslich. (2004). Etika Bisnis Islami. Yogyakarta: Ekonesia.

Sugiyono. 2011. Metode Penelitian Kuantitatif, Kualitatif dan R\&D. Bandung: Afabeta

Embun, B. (2012, April 17). Banjir Embun. Retrieved from Penelitian Kepustakaan: http://banjirembun.blogspot.co.id/2012/04/penelitian-kepustakaan.html 